\title{
Features of the material composition and possible technologies of pyrite cinders processing
}

\author{
Anatoly Borisovich MAKAROV ${ }^{1}$ \\ Gul'nara Gabdulbarievna KHASANOVA' \\ Mikhail Sergeevich GLUKHOV² \\ Maksim Andreevich PAN'SHIN ${ }^{3}$
}

${ }^{1}$ Ural State Mining University, Ekaterinburg, Russia

${ }^{2}$ Kazan (Volga region) Federal University, Kazan, Russia

3JSC "Uralelectromed", Verkhnyaya Pyshma, Sverdlovsk region, Russia

\begin{abstract}
Relevance of research is determined by the need to study for subsequent rational processing of technogenic mineral raw materials - pyrite cinders formed during firing pyritic concentrates for the production of sulfuric acid. Topical issues here are the determination of their chemical and mineral composition, morphology of particles, which predetermine possible technologies of their processing.

Purpose of research - study of the material composition of pyrite cinders of the dumps of the Kirovgrad coppersmelting plant, features identification of the composition of different-age dumps.

Methods of research. In the selected samples of pyrite cinders, their chemical composition was determined, the morphology of particles was studied by photographing them using the Philips XL-30 electron microscope equipped with an energy dispersive spectrometer (EDS), and possible processing technologies were analyzed.

Results. It was found that pyrite cinder of the old dump (no. 1) is characterized by low $\mathrm{SO}_{3}$ contents and low values of losses when firing relative to dump no. 2, which is determined by the oxidation of residual pyrite, as well as $\mathrm{CaO}$ and higher $\mathrm{Fe}_{2} \mathrm{O}_{3}$ contents. The study of the morphology of pyrite cinders microparticles showed that they have an irregular shape, globule shape and spherical size from $40 \mu \mathrm{m}$ to $2 \mathrm{~mm}$. Some known technologies of purple ore processing are considered.

Conclusion. The morphology of pyrite cinders particles and their chemical composition were determined as a result of the research. Taking into account the research results and morphostructural characteristics of cinders material, in particular, it is obvious that a number of technologies can be chosen for their complex processing; at the same time this determines further directions of their research, for example, the study of valuable impurity elements in them and their behavior in the process of changing the material of the dumps.
\end{abstract}

Keywords: dumps, technogenic formations, pyrite cynders, particles physiography, treatment processes.

Introduction

In recent years, great attention has been paid to the study and processing of man-made formations, which constitute an additional source of mineral raw materials [1-6]. The relevance of these studies is determined by obtaining the data necessary for the subsequent rational processing of data to assess the quality of technogenic mineral raw materials. Pyrite cinders are waste products of sulfuric acid production using the pyrite concentrate roasting technology. According to [7], currently only four of the largest storage facilities (LLC "Ammophos", OJSC "Minudobreniya", Kirovgrad Copper Smelting Plant and Priargunsky Industrial Mining and Chemical Association) contain more than 25 million tons of pyrite cinders. They are valuable technogenic raw materials but traditional methods of concentration such as gravity, flotation, and electromagnetic separation are ineffective for their processing [8]. One of the reasons for this is the poor knowledge of their material composition, as well as the morphology of these formations $[9,10]$.

\section{Brief description of research objects}

The object of the study was pyrite cinders of the Kirovgrad copper-smelting plant (currently Polymetal Production of JSC "Uralelectromed") located in the town of Kirovgrad, Sverdlovsk region; these pyrite cinders are located in two dumps (dump no. 1 was formed at first, then - no. 2). In dump no. 1 with planned dimensions of $500 \times 180 \mathrm{~m}$, the placement of cinders was carried out during the period of 1932-1955, their number amounted to 780 thousand tons; in dump no. 2, for the period 1956-1996, 3775 thousand tons of pyrite cinders were stored, the dump has a drop-shaped shape (fig. 1), the size of the dump is $1000 \times 500 \mathrm{~m}$, the thickness of the dumps reaches $12-15 \mathrm{~m}[5,11]$.

Pyrite cinders of the new dump (no. 2) represent a finely dispersed brownish, reddish-brown powder, in places slightly caked, particle density is $3.73 \mathrm{~g} / \mathrm{cm}^{3}$, moisture is 0.28 . Fine particles predominate in grain composition (0.05-2 mm - 56.5\%; 0.05-0.005-37.8\%; <0.005-1.8\%). 


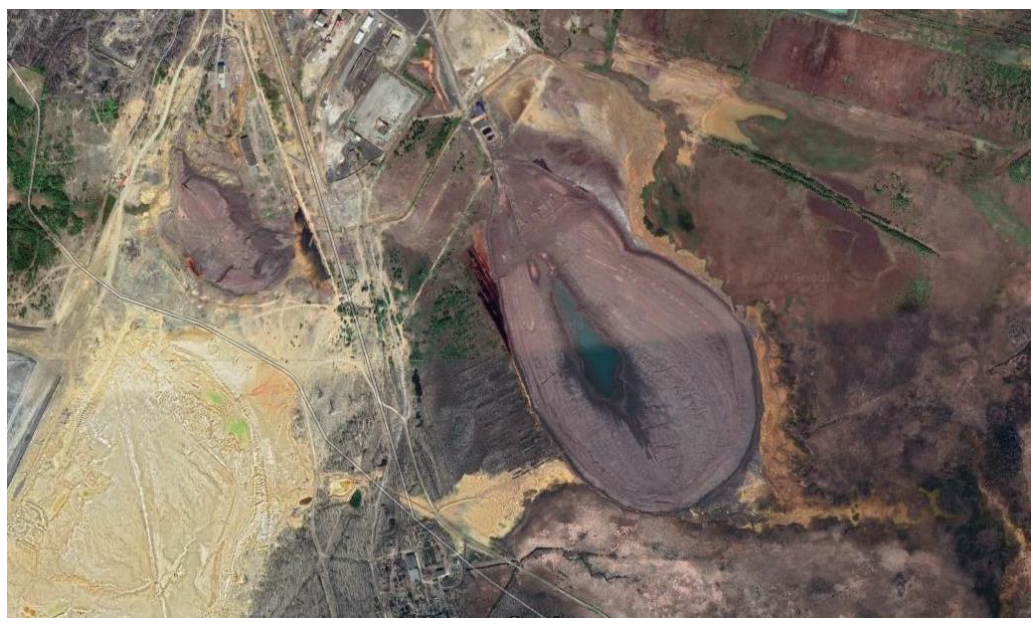

Figure 1. Dumps of pyrite cinders from the Kirovgrad Copper Smelter (source - Google Maps)

Рисунок 1. Отвалы пиритных огарков Кировградского медеплавильного комбината (источник - карты Google)

According to the results of X-ray analysis, hematite, magnetite and quartz predominate in the mineral composition; calcium and barium sulfate, oligoclase, pyrite and chalcopyrite can be found there [10]. The chemical composition of pyritic cougars is given in table 1 . The pyrite cinders of the old dump (no. 1), in addition to the loose material, are cemented in some areas; the color of the cinders of this dump is gray or dark gray.

The chemical composition of pyrite cinders (table 1) contains iron oxides, as well as alumina and silica, which is determined primarily by the composition of the pyrite concentrates used from local pyrite deposits of the Kirovgrad ore region. The content of the main oxides in the dumps generally does not change, a slight increase is observed according to $\mathrm{Fe}_{2} \mathrm{O}_{3}$ in the old dump (no. 1).

The most significant differences are associated with the migration of sulfur: in dump no. 1 , the $\mathrm{SO}_{3}$ content is $1.49-2.11$, which is probably determined by the oxidation of residual pyrite and the removal of sulfur from the dump; in dump no. 2 , its concentration is significantly higher: $4.48-5.41 \mathrm{wt}$. \%. This is also confirmed by the presence of segregations near the dump [10]. According to the results of earlier studies [10], the following impurity elements $(\mathrm{mg} / \mathrm{kg})$ were revealed in pyrite cinders of dump no. 2: copper - 1000-1500, zinc - 5000-7000, lead - 1000-1500, antimony - 30-70, nickel - 20-50, cobalt -20 , bismuth -4 , silver - 15-30. cinders

Material composition and morphology of pyritic

The morphology of the cinders was studied by photographing the surface of microparticles from the dumps using the Phillips XL-30 electron microscope equipped with an energy dispersive spectrometer (EMF), at an accelerating voltage of $20 \mathrm{keV}$ and a working distance of $8.9-15 \mathrm{~mm}$, a probing depth of $1.0-1.5 \mu \mathrm{m}$ and

Table 1. Chemical composition of pyrite cinders of the Kirovgrad Copper Smelting Plant, wt.\% Таблица 1. Химический состав пиритных огарков Кировградского медеплавильного комбината, мас.\%

\begin{tabular}{|c|c|c|c|c|}
\hline \multirow{3}{*}{ Oxydes } & \multicolumn{4}{|c|}{ Samples numbers } \\
\hline & \multicolumn{2}{|c|}{ Dump no. 1} & \multicolumn{2}{|c|}{ Dump no. 2} \\
\hline & 1 & 2 & 3 & 4 \\
\hline $\mathrm{SiO}_{2}$ & 8.57 & 6.740 & 8.07 & 8.68 \\
\hline $\mathrm{Al}_{2} \mathrm{O}_{3}$ & 18.41 & 17.500 & 16.45 & 14.50 \\
\hline $\mathrm{TiO}_{2}$ & 0.30 & 0.190 & 0.26 & 0.20 \\
\hline $\mathrm{Fe}_{2} \mathrm{O}_{3}$ & 53.83 & 58.210 & 60.74 & 59.11 \\
\hline $\mathrm{FeO}$ & 0.40 & 0.450 & 0.59 & 0.71 \\
\hline $\mathrm{MgO}$ & 1.20 & 1.200 & 0.89 & 1.10 \\
\hline $\mathrm{CaO}$ & 2.78 & 2.440 & 0.74 & 1.37 \\
\hline $\mathrm{MnO}$ & 0.04 & 0.025 & 0.03 & 0.04 \\
\hline $\mathrm{K}_{2} \mathrm{O}$ & 0.46 & 0.320 & 0.49 & 0.42 \\
\hline $\mathrm{Na}_{2} \mathrm{O}$ & 0.27 & 0.140 & 0.22 & 0.17 \\
\hline $\mathrm{P}_{2} \mathrm{O}_{5}$ & 0.14 & 0.041 & 0.18 & 0.09 \\
\hline $\mathrm{SO}_{3}$ & 2.11 & 1.490 & 4.48 & 5.41 \\
\hline $\begin{array}{l}\text { Percentage of other } \\
\text { impurities }\end{array}$ & 1.60 & 1.220 & 7.12 & 8.70 \\
\hline$\Sigma$ & 100.11 & 99.970 & 100.00 & 100.51 \\
\hline
\end{tabular}

The analyzes were carried out in the laboratory of physical and chemical methods of analysis, Faculty of Geology and Geophysics, Ural State Mining University. 

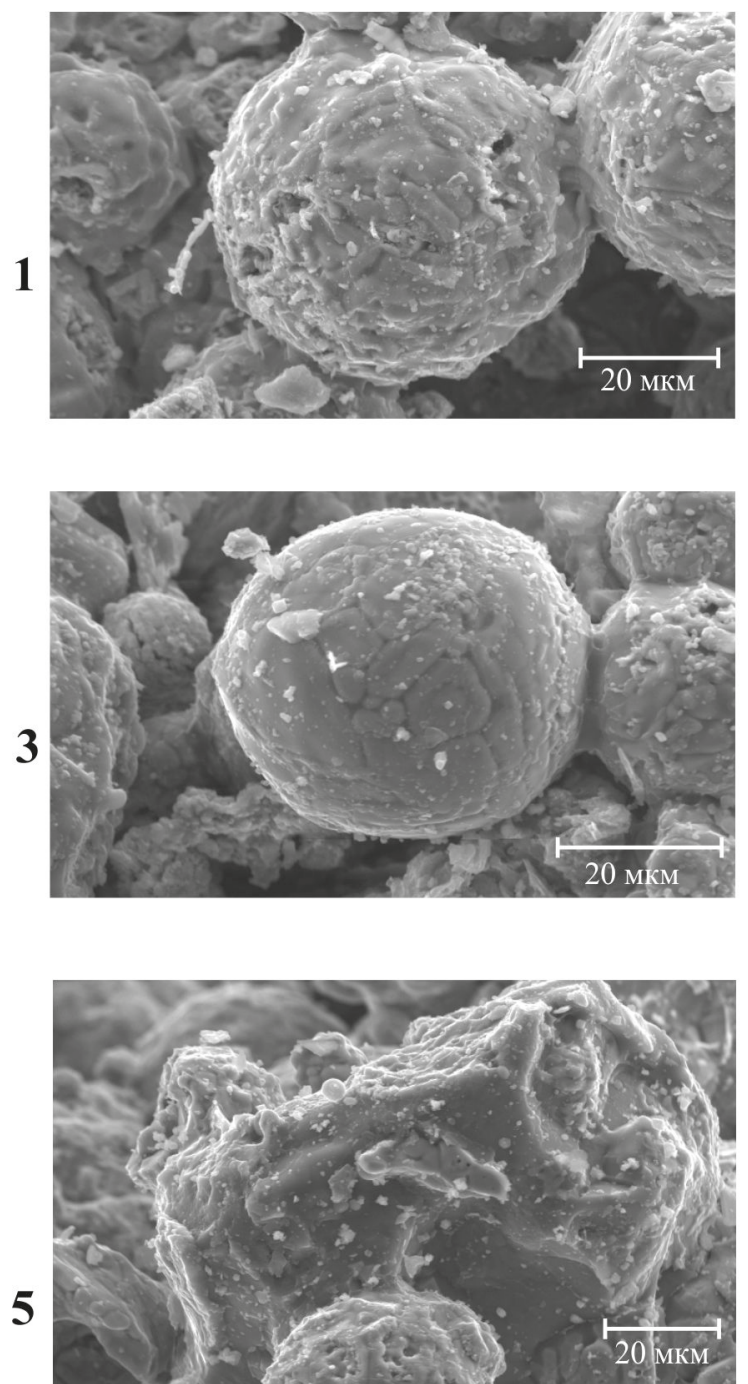
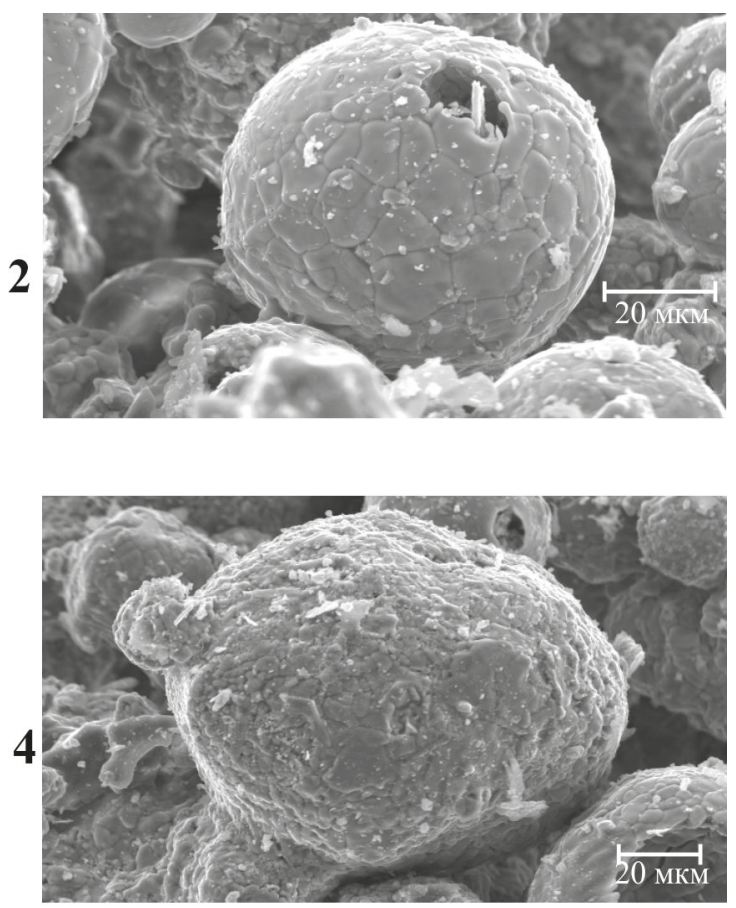

Figure 2. Morphology of particles of pyrite cinders from dump no. 1. Particle numbers correspond to the numbers of the analyzes given in table 2

Рисунок 2. Морфология частиц пиритных огарков отвала № 1. Номера частиц соответствуют номерам анализов, приведенным в табл. 2 a measurement accuracy of $0.1 \%$. All samples were coated with carbon before taking pictures. In total, $15 \mathrm{mi}-$ croparticles were photographed (6 from the "new" and 9 from the "old" dumps). EDS analysis was carried out for 10 objects (for 5 particles from each dump). The research technique was previously successfully used for similar micro-objects [12-14].

Visually, the samples are microparticles ranging in size from $40 \mu \mathrm{m}$ to $2 \mathrm{~mm}$ of irregular shape, in the form of globules and microspherules. The following textures are observed on the surface of irregularly shaped microparticles and globules: tuberous (fig. 2, photo 1), nodular (fig. 3, photo 8), spongy (fig. 3, photo 9) and rough (fig. 2 , photo 4 ; fig. 3 , photo 7 ). The microspherules are characterized by a block-mosaic texture (fig. 2, photos 2, 3). Such formations in dump no. 2 probably occur during the crystallization of finely scattered dispersed phases formed during the combustion of pyrite, i. e. the forming colloidal system, within which they condense in the form of separate globules - small rounded concretions of individual metal particles without any internal structure. In the process of further changes in the material in the dump, the cinder particles are transformed into fairly well-defined spherules, probably due to the change in the residual pyrite particles (fig. 2, photos 2,3 ), and the separation of individual quartz aggregates (fig. 2, photo 5). Similar transformations also reflect changes in the chemical composition of particles (table 2).

\section{Overview of possible processing technologies}

Several technologies have been proposed for processing pyrite cinders $[7,8,15]$. For example, for pyrite cinders of OJSC "Minudobrenie" (Meleuz), the VNIIsintezbelok Institute has proposed a processing technology using a bioproduct - yeast cell membranes that form biological complexes with gold and silver. OJSC "Atomredmetzoloto" has developed a technology for autoclave-absorption complex processing, which makes it possible to extract gold, silver, copper, zinc from them and use the processed cinders as raw materials for the manufacture of iron-containing pellets; VNIIHT - complex processing of autoclave-free technology using cyanidation. The use of bacteria in processing pyrite cinders makes it possible to obtain gold, non-ferrous metals and high-quality pigments without harmful impurities, and the cinders themselves after bacterial leaching are raw materials suitable for reductive roasting. Chloride-free technology for complex processing of pyrite cinders was proposed by the Institute of Metallurgy, Ural Branch of the Russian Academy of Sciences [11]. 

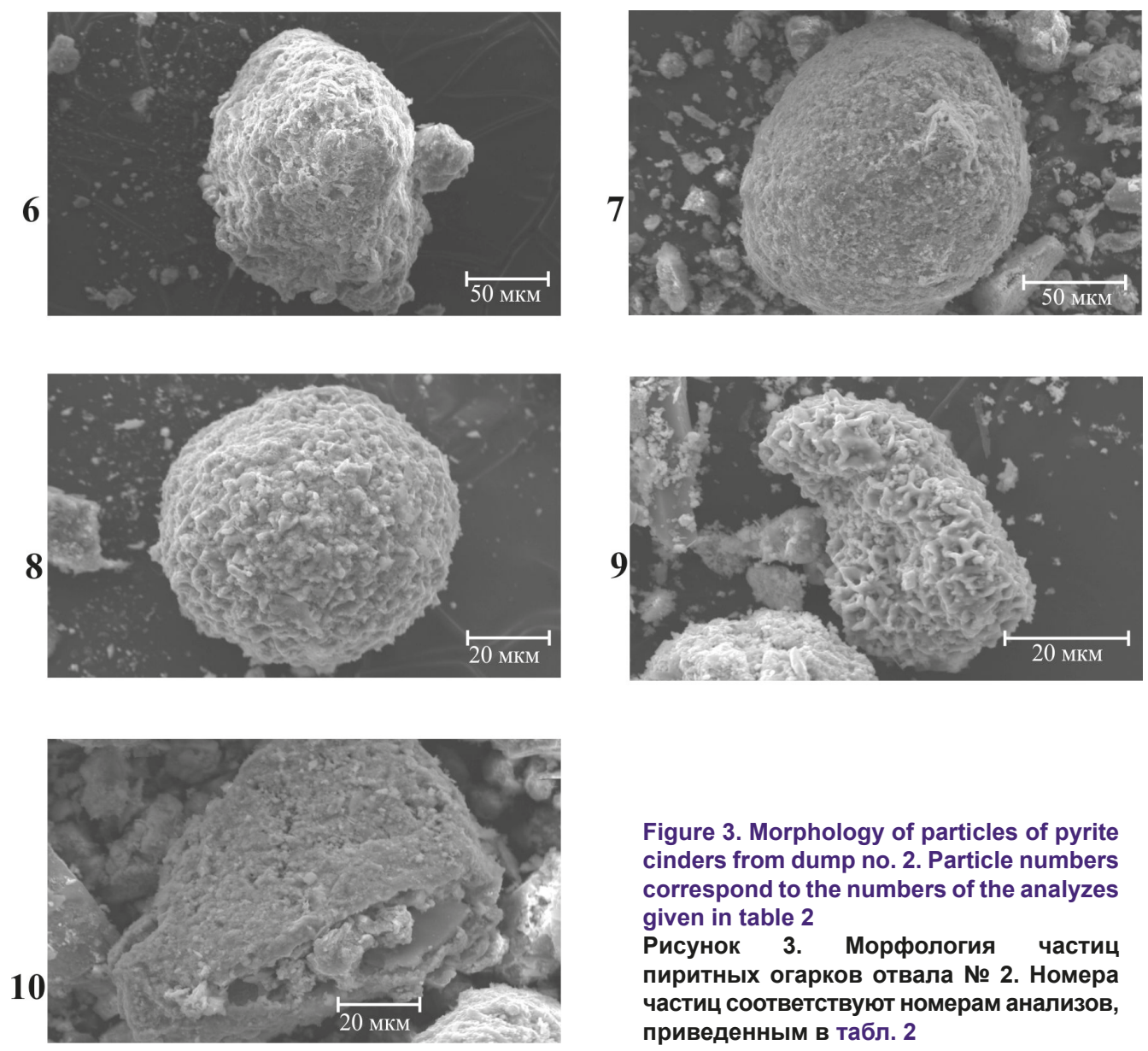

Figure 3. Morphology of particles of pyrite cinders from dump no. 2. Particle numbers correspond to the numbers of the analyzes given in table 2

Рисунок 3. Морфология частиц пиритных огарков отвала № 2. Номера частиц соответствуют номерам анализов, приведенным в табл. 2

The most rational method seems to be based on the reduction melting of pyrite cinders with the release of metallic iron or an alloy based on it, accumulating copper and noble metals. The formation of slags of the $\mathrm{Al}_{2} \mathrm{O}_{3}-\mathrm{CaO}-\mathrm{SiO}_{2}-\mathrm{FeO}$ system will make it possible to use the oxide component of the raw material, for example, as fused alumina cement. To implement the technology, a scheme is recommended including pelletizing the cinder together with a reducing agent and the mixture of $\mathrm{Al}_{2} \mathrm{O}_{3}$ - and $\mathrm{CaO}$-containing materials, heating the pellets to $1100-1150{ }^{\circ} \mathrm{C}$ and their subsequent melting at temperatures of $1450-1500^{\circ} \mathrm{C}$. Substandard $\mathrm{CaO}$ - and $\mathrm{Al}_{2} \mathrm{O}_{3}$-containing materials, for example, waste bauxite rocks, substandard alumina-carbonate raw materials or low-quality bauxite - are proposed as fluxes. The main technological parameters of the process including the consumption of the reducing agent (25-30\%), $\mathrm{CaO}$ and $\mathrm{Al}_{2} \mathrm{O}_{3}$-containing materials $(40-100 \%$ of the mass of the cinder), ensuring the extraction of $91.5-93 \%$ of zinc and $90-92 \%$ of lead - in sublimates; as well as $94-96 \%$ gold, $93-94 \%$ silver and $90-95 \%$ copper - in an alloy based on iron [7].

Table 2. Chemical composition of particles of pyrite cinders from dumps no. 1 and 2 Таблица 2. Химический состав частиц пиритных огарков отвалов № 1 и 2

\begin{tabular}{|c|c|c|c|c|c|c|c|c|c|c|c|}
\hline \multirow{2}{*}{$\begin{array}{l}\text { Particle } \\
\text { numbers }\end{array}$} & \multicolumn{11}{|c|}{ Elements, wt. \% } \\
\hline & $\mathrm{Fe}$ & $\mathrm{O}$ & $\mathrm{Al}$ & $\mathrm{Si}$ & $\mathrm{K}$ & $\mathrm{Na}$ & $\mathrm{Cu}$ & $S$ & $\mathrm{Ca}$ & $\mathrm{Mg}$ & Amount \\
\hline $1^{*}$ & 70.43 & 24.23 & 1.08 & 4.26 & - & - & - & - & - & - & 100 \\
\hline 2 & 67.70 & 30.96 & 0.74 & 0.60 & - & - & - & - & - & - & 100 \\
\hline 3 & 68.09 & 31.19 & 0.72 & - & - & - & - & - & - & - & 100 \\
\hline 4 & 30.10 & 35.43 & 1.90 & 17.72 & 0.40 & - & 2.54 & - & 5.28 & 6.63 & 100 \\
\hline 5 & 1.23 & 49.30 & 1.14 & 48.33 & - & - & - & - & - & - & 100 \\
\hline 6 & 9.32 & 51.31 & 11.95 & 17.97 & 3.70 & 0.53 & - & 4.31 & - & 0.92 & 100 \\
\hline 7 & 45.45 & 36.50 & 5.13 & 9.15 & 1.10 & - & - & 2.66 & - & - & 100 \\
\hline 8 & 50.11 & 44.96 & 1.90 & 1.77 & 0.29 & - & - & 0.97 & - & - & 100 \\
\hline 9 & 61.47 & 35.90 & 0.85 & 1.34 & - & - & - & 0.44 & - & - & 100 \\
\hline 10 & 40.90 & 49.71 & 2.12 & 2.15 & 1.15 & - & - & 3.97 & - & - & 100 \\
\hline
\end{tabular}

*Analysis numbers correspond to the numbers of micrographs (1-5-dump no. 1, 6-10-dump no. 2).

*Номера анализов соответствуют номерам микрофотографий (1-5 - отвал № 1, 6-10 - отвал № 2). 


\section{Conclusion}

As a result of the research, the morphology of pyrite cinder particles and their chemical composition were determined. Taking into account the research results and morphostructural characteristics of cinders material, in particular, it is obvious that a number of technologies can be chosen for their complex processing, at the same time this determines further directions of their research, for example, the study of valuable impurity elements in them and their behavior in the process of changing the material of the dumps.

\section{REFERENCES}

1. Akhmetov R. M. 2010, Problems of utilization of technogenic-mineral formations and their secondary use in the Southern Urals. Geology, minerals and problems of geoecology of Bashkortostan, the Urals and adjacent territories: Materials of the VIII Interregional scientific conference, Ufa, pp. 249-251. (In Russ.)

2. Danilov N. I., Smirnov L. A., Leschikov V. I. 2000, Experience in the disposal of technogenic formations in the Sverdlovsk region. Mineral'nyye resursy Rossii [Mineral resources of Russia], no. 5-6, pp. 41-51. (In Russ.)

3. Makarov A. B., Khasanova G. G., Talalay A. G. 2019, Technogenic deposits: research features. Izvestiya Ural'skogo gosudarstvennogo gornogo universiteta [News of the Ural State Mining University], issue 3 (55), pp. 58-62. (In Russ.) http://doi.org/10.21440/2307-2091-2019-3-58-62

4. Mustafin S. K. 2004, Gold in wastes of mining, concentration and processing mineral raw materials: Problems of assessment and extraction. All-Russian Research-to-Practice Conference called "Renovation: waste - technologies - income". III Scientific conference abstracts, Ufa, pp. 154-155. (In Russ.)

5. Mormil S. I., Salnikov V. L., Amosov L. A., et al. 2002, Technogenic deposits of the Middle Urals and assessment of their impact on the environment. Ekaterinburg, 206 p. (In Russ.)

6. Yakushina O. A., Ozhogina E. G., Khozyainov M. S. 2015, Microtomography of technogenic mineral raw materials. Vestnik geonauk [Vestnik of the Institute of Geology of the Komi Science Centre UB RAS], no. 11, pp. 38-43. (In Russ.) http://doi.org/10.19110/2221-1381-2015-11-38-43 7. Gulyaeva R. I., Shin S. N., Chumarev V. M., Selivanov E. N. 2017, Technology of complex processing of pyritic cinders. Proceedings of the Congress with international participation and the conference of young scientists called Fundamental research and applied development of the processing and utilization of technogenic formations of the V Forum, Ural market of scrap, industrial and municipal waste. Ekaterinburg, pp. 272-274. (In Russ.)

8. Fatkullin I. R. 2004, Pyrite cinders of OJSC "Minudobreniya" (Meleuz) are the valuable technogenic raw material. All-Russian Research-to-Practice Conference called "Renovation: waste - technologies - income". Scientific conference abstracts, Ufa, pp. 237-241. (In Russ.)

9. Makarov A. B., Glukhov M. S., Panshin M. A., Khasanova G. G. 2020, Morphology, chemical composition and possible technologies for processing pyrite cinders using the dumps of the Kirovgrad copper smelting plant as an example. Vestnik Ural'skogo otdeleniya Rossiyskogo mineralogicheskogo obshchestva [Proceedings of the Ural branch of the Russian Mineralogical Society], no. 17, pp. 66-70. (In Russ.) URL: https://repository.kpfu.ru/?p_id=244684

10. Makarov A. B., Guman O. M., Antonova I. A., Zakharov A. V. 2012, Technogenic and mineral deposits of pyrite cinders and their impact on the natural environment. Izvestiya Ural'skogo gosudarstvennogo gornogo universiteta [News of the Ural State Mining University], issue 27-28, pp. 38-45. (In Russ.)

11. Khasanova G. G. 2003, Methodological principles of cadastral assessment of technogenic-mineral formations of the Middle Urals . PhD thesis. Ekaterinburg, 17 p. (In Russ.)

12. Glukhov M. S., Sungatullin R. Kh., Galiullin B. M., Sungatullina G. M., Bakhtin A. I., Gusev A. V., Kuzina D. M. 2018, Metallic microspheres of cosmic and technogenic origin. Meteoritics \& Planetary Science, vol. 53, issue S1. 6202. URL: https://repository.kpfu.ru/?p_id=184028

13. Sungatullin R. Kh., Glukhov M.S., Galiullin B. M., Sungatullina G. M., Bakhtin A. I., Vishnykov A. K., Vafina M. S., Gusev A. V., Kuzina D. M. 2018, First finds of space microspheres in the evaporates of the Ural foredeep, Russia. Meteoritics \& Planetary Science, vol. 53 , no. S1. 6291. URL: https://repository.kpfu.ru/?p_id=182095

14. Veerle C., Boone M. 2013, High-resolution X-ray computed tomography in geosciences: a review of the current technology and applications. Earth-Science Reviews, vol. 123, pp. 1-17. URL: http://hdl.handle.net/1854/LU-3232121

15. Shin S. N., Chumarev V. M., Gulyaeva R. I. 2004, An improved version of the chloride-free technology of complex processing of pyrite cinders. Ecological problems of industrial regions: materials of the All-Russian conference. Ekaterinburg, pp. 324-325. (In Russ.) 


\title{
Особенности вешественного состава и возможные технологии переработки пиритных огарков
}

\author{
Анатолий Борисович МАКАРОВ ${ }^{1}$ \\ Гульнара Габдулбариевна ХАСАНОВА ${ }^{1}$ \\ Михаил Сергеевич ГЛУХОВ 2 \\ Максим Андреевич ПАНЬШИН ${ }^{3}$
}

1Уральский государственный горный университет, Екатеринбург, Россия

${ }^{2}$ Казанский (Приволжский) фредеральный университет, Казань, Россия

${ }^{3} \mathrm{AO}$ «Уралэлектромедь», Верхняя Пышма, Свердловская область, Россия

\section{Аннотация}

Актуальность исследований - необходимость изучения для последующей рациональной переработки техногенного минерального сырья - пиритных огарков, образующихся при обжиге пиритных концентратов для получения серной кислоты. Определение их химического и минерального состава, морфологии частиц, что предопределяет возможные технологии переработки.

Цель исследований - изучение вещественного состава пиритных огарков отвалов Кировградского медеплавильного комбината, выявление особенностей состава образований разновозрастных отвалов.

Методы изучения. В отобранных пробах пиритных огарков определялся их химический состав, морфология частиц изучалась путем их фотографирования с применением электронного микроскопа Philips XL-30, оснащенного энергодисперсионным спектрометром (ЭДС), проанализированы возможные технологии переработки.

Peзультаты. Установлено, что для пиритных огарков старого отвала (№ 1) характерны пониженные содержания $\mathrm{SO}_{3}$ и низкие значения потерь при прокаливании относительно отвала № 2, что определяется окислением остаточного пирита, а также $\mathrm{CaO}$ и более высокие содержания $\mathrm{Fe}_{2} \mathrm{O}_{3}$. Изучение морфологии микрочастиц пиритных огарков показало, что они имеют неправильную форму, форму глобулей и сферичную размером от 40 мкм до 2 мм. Рассмотрены известные к настоящему времени технологии переработки пиритных огарков.

Вывод. В результате исследований определены морфология частиц пиритных огарков и их химический состав. С учетом результатов исследований, в частности морфоструктурной характеристики материала огарков, становится очевидным, что для их комплексной переработки можно выбрать целый ряд технологий, в то же время это определяет дальнейшие направления их исследования, в частности - изучение в них ценных элементов-примесей и их поведения в процессе изменения материала отвалов.

Ключевые слова: отвалы, техногенные образования, пиритные огарки, морфология частиц, технологии переработки.

\section{ЛИТЕРАТУРА}

1. Ахметов Р. М. Проблемы утилизации техногенно-минеральных образований и их вторичного использования на Южном Урале // Геология, полезные ископаемые и проблемы геоэкологии Башкортостана, Урала и сопредельных территорий: материалы VIII Межрегион. науч.-практ. конф. Уфа: ДизайнПолиграфСервис, 2010. С. 249-251.

2. Данилов Н. И., Смирнов Л. А., Лещиков В. И. Опыт утилизации техногенных образований в Свердловской области // Минеральные ресурсы России. 2000. № 5-6. С. 41-51.

3. Макаров А. Б., Хасанова Г. Г., Талалай А. Г. Техногенные месторождения: особенности исследований // Известия УГГУ. Вып. 3 (55). 2019. C. 58-62. http://doi.org/10.21440/2307-2091-2019-3-58-62

4. Мустафин С. К. Золото в отходах добычи, обогащения и переработки минерального сырья: проблемы оценки и извлечения // Реновация: отходы - технологии - доходы: тез. докл. III Всерос. науч.-практ. конф. Уфа. 2004. С. 154-155.

5. Мормиль С. И., Сальников В. Л., Амосов Л. А. и др. Техногенные месторождения Среднего Урала и оценка их воздействия на окружающую среду. М., 2002. 206 с.

6. Якушина О. А., Ожогина Е. Г., Хозяинов М. С. Микротомография техногенного минерального сырья // Вестник ИГ Коми НЦ УрО РАН. 2015. № 11. С. 38-43. http://doi.org/10.19110/2221-1381-2015-11-38-43

7. Гуляева Р. И., Шин С. Н., Чумарев В. М., Селиванов Е. Н. Технология комплексной переработки пиритных огарков // Фундаментальные исследования и прикладные разработки процессов переработки и утилизации техногенных образований: Труды Конгресса с междунар. участием и конференции молодых ученых V форума «Уральский рынок лома, промышленных и коммунальных отходов». Екатеринбург: УрО РАН, 2017. С. 272-274.

8. Фаткуллин И. Р. Пиритные огарки ОАО «Минудобрения» (г. Мелеуз) - ценное техногенное сырье // Реновация: отходы - технологии доходы: тез. докл. Всерос. науч.-практ. конф. Уфа, 2004. С. 237-241. 
9. Макаров А. Б., Глухов М. С., Паньшин М. А., Хасанова Г. Г. Морфология, химический состав и возможные технологии переработки пиритных огарков (на примере отвалов Кировградского медеплавильного комбината) // Вестник УрО РМО. 2020. № 17. С. 66-70. URL: https://repository.kpfu.ru/?p_id=244684

10. Макаров А. Б., Гуман О. М., Антонова И. А., Захаров А. В. Техногенно-минеральные месторождения пиритных огарков, их влияние на природную окружающую среду // Известия УГГУ. 2012. Вып. 27-28. С. 38-45.

11. Хасанова Г. Г. Методические принципы кадастровой оценки техногенно-минеральных образований Среднего Урала: автореф. дис. ... канд. геол.-минерал. наук. Екатеринбург, 2003. 17 с.

12. Glukhov M. S., Sungatullin R. Kh., Galiullin B. M., Sungatullina G. M., Bakhtin A. I., Gusev A. V., Kuzina D. M. Metallic microspheres of cosmic and technogenic origin // Meteoritics \& Planetary Science. 2018. Vol. 53. Issue S1. 6202. URL: https://repository.kpfu.ru/?p_id=184028

13. Sungatullin R. Kh., Glukhov M. S., Galiullin B. M., Sungatullina G. M., Bakhtin A. I., Vishnykov A. K., Vafina M. S., Gusev A. V., Kuzina D. M. First finds of space microspheres in the evaporites of the Ural foredeep, Russia // Meteoritics \& Planetary Science. 2018. Vol. 53. No. S1. 6291. URL: https://repository.kpfu.ru/?p_id=182095

14. Veerle C., Boone M. High-resolution X-ray computed tomography in geosciences: a review of the current technology and applications // Earth-Science Reviews. 2013. Vol. 123. P. 1-17. URL: http://hdl.handle.net/1854/LU-3232121

15. Шин С. Н., Чумарев В. М., Гуляева Р. И. Усовершенствованный вариант бесхлоридной технологии комплексной переработки пиритных огарков // Экологические проблемы промышленных регионов: материалы Всерос. конф. Екатеринбург, 2004. С. $324-325$.

Статья поступила в редакцию 17 марта 2021 года 